Revista Latinoamericana de la Papa 21 (2): 69 - 88

ISSN: 1853-4961

http://www.papaslatinas.org/revista.html

\title{
Potato crop health quality and yield losses in Ecuador
}

\section{Navarrete ${ }^{1}$, N. Panchi ${ }^{1}$, J.L. Andrade-Piedra ${ }^{2}$}

Received: 07/11/2017

Accepted: $28 / 11 / 2017$

Accessible on line: December 2017

\begin{abstract}
Summary
The poor knowledge about the presence of diseases and pests affecting the potato crop in developing countries difficult the understanding of their distribution in agro-ecological systems and consequent effect on yield and seed quality. A combination of a monitoring and a field experiment were performed to: (1) determine the incidence and severity of pathogens and pests affecting foliage and seed tubers, (2) determine the influence of altitude and seed sources over seed quality, and (3) determine yield responses to seed quality. Disease and pest monitoring on the foliage and seed tubers was performed in farmers' fields in the main potato production provinces in Ecuador in 2010. The field experiment was performed in CIP-Quito by planting the evaluated seed tubers from 20102011 and registering their individual yield. We found that late blight and flea beetle damages were constantly affecting foliage, whereas black scurf, andean weevil, potato virus $\mathrm{S}$ and potato virus $\mathrm{X}$ predominantly affected seed tubers. Our data suggest that planting at higher altitudes potentially reduce seed-borne viral diversity, and that pathogens and pests diversity on farmers' seed tubers is similar regardless the seed source. Yield variation was explained by the following problems in the seed tuber: black scurf, presence of potato virus $\mathrm{S}$, potato yellow vein virus, and presence of mechanical damages. However, these problems varied when seed source or variety changed.
\end{abstract}

Additional keywords: Degeneration, Seed-borne pests, incidence, virus, yield, diversity.

Calidad fitosanitaria del cultivo de papa y sus pérdidas en rendimiento en el Ecuador

\section{Resumen}

El pobre conocimiento acerca de la presencia de las enfermedades y plagas que afectan al cultivo de papa en países en desarrollo limita el entendimiento de su distribución en sistemas agro-ecológicos y su efecto consecuente en el rendimiento y la calidad de semilla. Una combinación de monitoreo y experimento en campo se realizaron para: (1) determinar la incidencia y severidad de patógenos y plagas que afectan al follaje y a los tubérculos semillas, (2) determinar la influencia de la altitud y las fuentes de semilla sobre la calidad de semilla, y (3) determinar las respuestas de rendimiento sobre la calidad de semilla.

\footnotetext{
* Corresponding autor. Electronic mail: israelnavarrete2@gmail.com

${ }^{1}$ Research Assistant, International Potato Center. Quito

${ }^{2}$ Seed and epidemiology of biotic stress specialist, International Potato Center. Lima
} 
Enfermedades y plagas en el follaje y en los tubérculos semillas fueron monitoreados en campos de agricultores en las principales provincias del Ecuador en el 2010. El experimento en campo se realizó en las facilidades de CIP-Quito durante el 2010 y el 2011. Esto se hizo plantando los tubérculos semillas evaluados y registrando el efecto individual de estos tubérculos semillas en rendimiento. Los resultados muestran que lancha y daños de pulguilla constantemente afectaron al follaje, mientras que el gusano blanco, el virus $\mathrm{S}$ de la papa y el virus $\mathrm{X}$ afectaron predominantemente los tubérculos semillas. Nuestros datos sugieren que plantar en lotes ubicados a elevadas alturas potencialmente reduce la diversidad de virus transmitidos por semilla y que la diversidad de patógenos y plagas en los tubérculos semilla del agricultor es similar a otras fuentes de semilla. La variación del rendimiento fue explicada por los siguientes problemas transmitidos en los tubérculos semilla: costra negra, presencia de virus $\mathrm{S}$ de la papa, presencia del virus del amarillamiento de las venas, y presencia de daños mecánicos. Sin embargo, estos problemas variaron cuando fuentes de semilla y las variedades fueron consideradas.

Palabras clave adicionales: Degeneración, plagas transmitidas por semilla, incidencia, virus, rendimiento, diversidad.

\section{Introduction}

Yield of the potato crop in Ecuador (11.5 $\mathrm{t} \mathrm{ha}^{-1}$ ) is relatively low in comparison with neighbouring countries like Colombia (18.08 $\left.\mathrm{t} \mathrm{ha}^{-1}\right)$ and Peru (14.7 t $\mathrm{ha}^{-1}$ ) (FAO 2016, SINAGAP 2017). This is limited, in part, by the high disease and pest pressure present around the entire year. The poor monitoring deepens this situation because outbreak detections of new and already existing diseases and pests are neglected, and therefore, complicating the design of effective management strategies to control these problems and increase yield.

Important examples are found among the foliar diseases and pests that limit potato production. Late blight (Phytophthora infestans), for instance, is widely known for its proximate role on the Irish famine in 1845 (Bourke 1993), and for the considerable amount of economic resources that are invested to control this disease (Kromann et al. 2014). The potato tuber moth complex is also another example. It is composed by three species Tecia solanivora, Phthorimaea operculella and Symmetrischema tangolias (Dangles et al. 2009). Yield losses caused by this complex reach up to $40 \%$ on the field and up to $100 \%$ at postharvest (Palacios et al. 1997).

Production is also limited by the type of seed-borne pathogen infecting or pest damaging the seed tuber. Viruses cause yield losses ranging from 10 to $90 \%$ (Salazar 2003), fungi like Rhizoctonia solani causes yield losses around 20 to 30\% (Banville 1989, Fankhauser 2000), and pest damages like the Andean potato weevil reduce the marketable price in about 20 to $50 \%$ (Oyarzún et al. 2002a). However, the effect of multiple and simultaneous infections/damages on the seed tuber on yield is poorly understood, especially in the Ecuadorian Andes, where agro-ecological conditions are highly diverse.

Besides reducing yield, seed-borne diseases and pests reduce tuber seed quality (referred to seed health). Among these, viruses are usually considered the main cause of seed quality reduction, especially Potato Leafroll Virus (PLRV), Potato Virus A (PVA), Potato Virus S 
(PVS), Potato Virus X (PVX), and Potato Virus Y (PVY) (Salazar 2003, Scholthof et al. 2011). Other seed-borne pathogens and pests decreasing seed quality are $R$. solani, Ralstonia solanacearum, Pectobacterium spp., Globodera spp, (5) Meloidogyne spp., Tecia solanivora, among others (Thomas-Sharma et al. 2016).

Unfortunately, seed-borne diseases and pests are rarely monitored. In the case of Ecuador, the situation of seed-borne problems was reported more than a decade ago by Fankhauser (2000). The main results indicated that $R$. solani, Streptomyces scabies and Premnotrypes vorax were the most important pathogens and pests decreasing seed quality: incidence on tubers reached up to $78 \%$ for R. solani, $28 \%$ for S. scabies, and $33 \%$ for $P$. vorax, and reducing yield between 17 and $30 \%$. Results of this study also showed that tubers had a low incidence of PLRV (<3\%), PVY (<3\%), PYVV $(<2 \%)$, but a high incidence of PVX (up to $14 \%$ ) and PVS (up to $96 \%$ ).

Farmers' practices consider strategically agro-ecological conditions to improve or maintain seed quality. One of the examples is planting seed tubers harvested in high altitude fields (Struik and Wiersema 1999, Almekinders and Louwaars 2002). Different experiments support the effect of this practice by suggesting that at higher altitudes (above 2500 m.a.s.l) the mechanisms of seedborne virus dissemination are limited due to a negative correlation between altitude and temperature that decreases vector populations and secondary viral infections (Sanchez de Luque et al. 1991, Bertschinger 1992, Fankhauser 2000).
Bertschinger et al. (1990), in contrast, reported the lack of altitude influence on seed quality. This contrasting evidence suggest that further research is needed to understand when the flow of seed tubers from high altitudes would be beneficial.

Moreover, it is frequently believed that farmers' seed tubers is of poor quality due to seed degeneration (Bertschinger et al. 1990, Thomas-Sharma et al. 2016). However, evidence found in experiments performed in Peru suggest that there is no difference in seed quality among the different seed sources (markets, farmers exchange, self-production, or formal system) (Bertschinger et al. 1990). Unfortunately, seed quality in Ecuador from different seed sources has not been properly assessed yet.

Hence, here we report the results of a monitoring exercise combined with a field experiment to: (1) determine the incidence and severity of foliage and seed-borne pathogens and pests affecting the potato crop in Ecuador; (2) understand how altitude and seed sources affect seed quality; and (3) estimate the effect of seed quality on yield.

\section{Materials and Methods}

\section{Incidence and severity of seed-borne pests}

In 2010, eleven fields owned by small scale farmers of the Consortium of Small Potato Producers (CONPAPA in Spanish) were selected in three provinces of Ecuador: Bolivar, Chimborazo and Tungurahua. The provinces were selected based on the number of hectares of potatoes cultivated, poverty levels, and presence of partner institutions. 
Table 1. Field location, potato varieties and seed sources in a monitoring conducted in the central highlands of Ecuador in 2010.

\begin{tabular}{|c|c|c|c|c|c|c|}
\hline Province & Altitude & Latitude & Longitude & Variety & Seed source $^{1}$ & $\operatorname{Area}\left(\mathbf{m}^{2}\right)$ \\
\hline \multirow{4}{*}{ Bolívar } & 3596 & ${\mathrm{~S} 01^{\circ} 32^{\prime} 52.4^{\prime \prime}}$ & W 78 55’14.5" & Dolores & Self-provided & 238 \\
\hline & 2812 & $\mathrm{~S} 01^{\circ} 38^{\prime} 38.8^{\prime \prime}$ & W $78^{\circ} 58^{\prime} 29.1^{\prime \prime}$ & INIAP-Fripapa & \multirow{2}{*}{$\begin{array}{l}\text { Formal system } \\
\text { (G3) } \\
\text { Self-provided }\end{array}$} & 803 \\
\hline & 2751 & $\mathrm{~S} 01^{\circ} 40^{\prime} 48.3^{\prime \prime}$ & W 78 $57^{\prime} 34.1^{\prime \prime}$ & Única & & 1375 \\
\hline & 2793 & $\mathrm{~S} 01^{\circ} 40^{\prime} 45.0^{\prime \prime}$ & W $78^{\circ} 57^{\prime} 26.8^{\prime \prime}$ & INIAP-Yana Shungo & $\begin{array}{l}\text { Formal } \\
\text { (G4) }\end{array}$ & 220 \\
\hline \multirow{5}{*}{ Chimborazo } & 3576 & $\mathrm{~S} 01^{\circ} 36^{\prime} 31.6^{\prime \prime}$ & W $78^{\circ} 48^{\prime} 21.8^{\prime \prime}$ & Chaucha Roja & Market & 888 \\
\hline & 3566 & $\mathrm{~S} 01^{\circ} 36^{\prime} 33.1^{\prime \prime}$ & W $78^{\circ} 48^{\prime} 22.0^{\prime \prime}$ & Chaucha Roja & Market & 277 \\
\hline & 3455 & 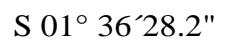 & W $78^{\circ} 46^{\prime} 49.3^{\prime \prime}$ & INIAP-Gabriela & Self-provided & 375 \\
\hline & 3601 & $\mathrm{~S} 01^{\circ} 38^{\prime} 28.9^{\prime \prime}$ & W 78॰47'48.4" & Chaucha Roja & Self-provided & 539 \\
\hline & 3527 & $\mathrm{~S} 01^{\circ} 34^{\prime} 25.1^{\prime \prime}$ & W 78 46’37.1" & INIAP-Gabriela & Self-provided & 757 \\
\hline \multirow[t]{2}{*}{ Tungurahua } & 3634 & $\mathrm{~S} 01^{\circ} 18^{\prime} 21.4^{\prime \prime}$ & $\mathrm{W} 78^{\circ} 46^{\prime} 41.1^{\prime \prime}$ & INIAP-Fripapa & \multirow{2}{*}{$\begin{array}{l}\text { Formal system } \\
\text { (G3) } \\
\text { Self-provided }\end{array}$} & 618 \\
\hline & 3035 & $\mathrm{~S} 01^{\circ} 06^{\prime} 26.7^{\prime \prime}$ & W 78 32’00.2" & Única & & 569 \\
\hline
\end{tabular}

${ }^{1}$ The "G" notation refers to the number of successive plantings from in-vitro plants (Salazar 1995b). For the case of Ecuador, the seed G3 corresponds to the category "Registrada" and G4 to the category "Certificada".

Fields were selected depending on the altitude (between 2751 and 3634 m.a.s.1), planted variety, and farmer's eagerness to collaborate. Field area ranged between 220 and $1776 \mathrm{~m}^{2}$, and were planted with any of these six varieties: Chaucha Roja, Dolores, INIAP-Yana Shungo, INIAPFripapa, INIAP-Gabriela and Única. In ten out of the 11 fields, incidence and severity of foliage diseases and insect damages were assessed in 100 randomly selected plants at flowering by using the keys proposed by Cruickshank et al. (1982) (number of plants per variety: Chaucha Roja $=200$, Dolores $=100$, INIAP-Fripapa $=200$, INIAP-Gabriela $=$ 200, Única $=200$, INIAP-Yana Shungo $=$ 100). Farmers were also asked to identify their seed sources. At harvest, farmers selected the best 400 tubers from each of the 11 fields and taken to the facilities of the International Potato Center in Quito (CIP-Quito, 3058 m.a.s.1, 0²2' S, 78³3' W). Tubers were washed, and incidence and severity of pests and diseases were visually assessed in each tuber as described by James (1971). Physical and physiological issues on the tubers were registered in this monitoring excluding nematodes. Number of tubers assessed per variety were: Chaucha Roja $=1017$, Dolores $=400$, INIAP-Fripapa $=800$, INIAP-Gabriela $=800$, Única $=855$, INIAP-Yana Shungo $=400$.

Tubers were then stored in diffused light, covered with an anti-aphid net, and protected with insecticide (commercial name: Malathion ${ }^{\circledR} 50 \mathrm{PM}$; a.i, malathion, concentration: $500 \mathrm{~g} / \mathrm{kg}$ of product; dose: $5 \mathrm{~g}$ of product/L) to prevent aphid infestation, until sprouting occurred naturally. A subsample of approximately 100 seed tubers was randomly selected out of the 400 seed tubers (selected per field) for virus diagnoses (number of 
Revista Latinoamericana de la Papa 21 (2): 69 - 88

tubers sampled per variety: Chaucha Roja $=404$, Dolores $=103$, INIAP-Fripapa $=$ 240, INIAP-Gabriela $=237$, Única $=286$, INIAP-Yana Shungo $=90$ ). To do this, one to five sprouts (2 to $3 \mathrm{~cm}$ long) of each tuber were collected. Sprouts were disinfested (3\% solution of Captan [i.a., Captan, dose; $1.5 \mathrm{~g} / \mathrm{L}$ idem]) and planted in trays in a net house at CIP-Quito, until having plants 8 to $10 \mathrm{~cm}$ tall. Plants were then transplanted into $3-\mathrm{kg}$ pots and protected with an anti-aphid net until they were 15 to $20 \mathrm{~cm}$ tall. Leaf samples from the top, middle and bottom of the plant were taken and pooled together. Tubers used for virus diagnosis were put back into diffused light storage until new sprouts appeared, and were used in the field experiment described below.

DAS-ELISA and NASH (Nucleic Acid Spot Hybridization) were performed for virus diagnosis using materials provided by the Virology Unit at CIP in Lima, Peru. DAS-ELISA was carried out according to the protocol proposed by CIP (2007) to detect the following viruses: Andean Potato Latent Virus (APLV), Andean Potato Mottle Virus (APMoV), PLRV, PVA, PVS, PVX, PVY. After completing DAS-ELISA, positive samples were determined by visual observation when samples turned yellow. Positive and negative controls were obtained from the National Agricultural Research Institute (INIAP in spanish) laboratory of Biotechnology and the BIOREBA company.

NASH was performed to detect Potato Yellow Vein Virus (PYVV) according to the protocols for Potato spindle tuber viroid proposed by CIP (1993a) and CIP (1993b). The samples were prepared in the laboratory of CIP-Quito and then sent to the facilities of CIP in Lima for virus detection. To prepare the samples, briefly, nitrocellulose membranes were soaked in distilled water, washed twice with SSC 20X, and dried at ambient air. Then, leaf samples were macerated with two volumes of extraction buffer $(49.4 \mathrm{ml}$ of Formaldehyde $(37 \%)+50.6 \mathrm{ml}$ of SSC 10X). These extracts were transferred to Eppendorf tubes and centrifuged at 12000 rpm per 5 minutes. After centrifugation, an aliquot of 3-4 $\mu \mathrm{L}$ of the supernatant was transferred to the membranes and dried at ambient air. Finally, membranes were baked at $80{ }^{\circ} \mathrm{C}$ for two hours.

Incidence was calculated as the percentage of plants with positive reaction in DAS-ELISA/nitrocellulose membranes in relation to the total number of plants.

\section{Yield losses caused by seed-borne pests}

In order to understand yield losses as a response to seed quality, a field experiment was carried out by planting a random subsample of 1360 seed tubers (experimental unit $=$ one seed tuber) coming from the previous monitoring (therefore pest incidence and severity and virus presence was known for each tuber). The field experiment was established from October 2010 until December 2011 at CIP-Quito (average temperature $12.3^{\circ} \mathrm{C}$ and average accumulated rainfall per month $175 \mathrm{~mm})$. Seed tubers were planted when sprouts were 1 to $2-\mathrm{cm}$ long. Tubers from the same variety-field combination were planted together in 75$\mathrm{m}^{2}$ plots. These plots were randomly allocated in a $2325-\mathrm{m}^{2}$ plot. The fallow space between each $75-\mathrm{m}^{2}$ plot was 2.7 $\mathrm{m}$. Planting was done at $0.4 \mathrm{~m}$ between plants and $1.2 \mathrm{~m}$ between rows. Certified seed tubers (G4; [Salazar 1995]) of INIAP-Fripapa were planted between 
experimental units to avoid cross contamination. Plants were then labelled individually. Agronomic practices were done following local recommendations (Oyarzún et al. 2002a, Oyarzún et al. 2002b). Plants were harvested individually when reached full maturity (130 to 180 days after planting, depending on the variety) and yield was measured (g plant $\left.{ }^{-1}\right)$.

\section{Statistical analysis}

An analysis of incidence and severity of foliage and seed-borne pests were performed using descriptive statistics. Incidence data of seed-borne pests were used to calculate the Shannon index, which provided an estimate of pathogen and pest diversity as a function of variety, seed source and altitude. It was calculated as described by Kosman (1996) and Perez et al. (2001) as follows $H s=-\Sigma_{j}\left(p_{j} \mathrm{x} \ln \left(p_{j}\right), j=1 \ldots n_{p}\right.$, where $p_{j}$ is the frequency of the $i$ th seedborne pest and pathogen, and $n_{p}$ is the number of seed-borne pests and pathogens identified. An additional Shannon index was calculated only including viruses. Using the program " $R$ " (version 3.3.2), a multiple linear regression was performed (command $\mathrm{lm}$ ) to estimate the effect of seed quality (pest and pathogen incidence and severity) on yield loss. Assumptions of linearity were assessed by the default diagnostic plots of the program and the variance inflation factor (Car package, command vif) (Faraway 2016; Fox et al. 2016).

In order to deal with multicollinearity, a general regression model adjusting by the effects of the varieties was performed, and then the most meaningful parameters were selected. With these parameters, regressions were obtained per each seed source and potato variety. Raw data collected during the monitoring and field experiments (including weather data for the field experiment) was deposited in the CIP Dataverse Repository: http://dx.doi.org/10.21223/P3/XVAGXC (Navarrete et al. 2016)

\section{Results}

During our monitoring, we identified three seed sources: (1) Self provided, (2) market, and (3) formal system (Table 1). The varieties Chaucha Roja, Dolores, INIAP-Gabriela and Única were selfprovided by the farmers. Chaucha Roja from one farmer's field was the only variety acquired in the market, and INIAP - Fripapa and INIAP- Yana Shungo (Table 1) were obtained from the formal system.

\section{Incidence and severity of foliage diseases, insect pests and seed-borne pests}

We identified five foliage diseases and eight pests. Diseases found were: black leg (Pectobacterium sp.), common rust of potato (Puccinia pitteriana), early blight (Alternaria solani), late blight (Phytophthora infestans), and stem canker (Rhizoctonia solani). Insect damages found were: Andean potato weevil (Premnotrypes vorax), aphids (several species involved such as Macrosiphum sp. or Myzus sp.), leafminer (Liriomyza spp.), potato flea beetle (Epitrix spp.), thrips (Frankliniella tuberosi), white grub (Barotheus sp), white fly (Bemisia sp. or Trialeurodes vaporariorum), and wireworm (Agriotes sp.). From this list, the most predominant diseases were late blight and common rust of potato. Average incidence of late blight was $65.9 \%$ and severity $15 \%$. The lowest incidence was registered in variety INIAP-Yana Shungo (2\%) and the highest was in Dolores (97\%). The 
second most prevalent disease was common rust of potato with an average incidence of $17 \%$ and severity of $1.3 \%$. Varieties showing the lowest incidence were Chaucha roja and INIAP-Yana Shungo (0\%); while the highest was found on the variety INIAP-Fripapa $(49 \%)$.

Table 2. Incidence and severity of foliage diseases and insect pests in six potato varieties in Ecuador (for the number of observations see Materials and Methods).

\begin{tabular}{|c|c|c|c|c|c|c|c|c|c|c|c|c|c|c|}
\hline & \multicolumn{3}{|c|}{ Dolores } & \multicolumn{3}{|c|}{ Chaucha Roja } & \multicolumn{3}{|c|}{ INIAP-Yana Shungo } & \multicolumn{3}{|c|}{ INIAP-Fripapa } & \multicolumn{2}{|c|}{ INIAP-Gal } \\
\hline & \multirow{2}{*}{$\begin{array}{c}\text { Incidence } \\
(\%)\end{array}$} & \multicolumn{2}{|c|}{$\begin{array}{c}\text { Severity } \\
(\%)\end{array}$} & \multirow{2}{*}{$\begin{array}{c}\text { Incidence } \\
(\%)\end{array}$} & \multicolumn{2}{|c|}{$\begin{array}{c}\text { Severity } \\
(\%)\end{array}$} & \multirow{2}{*}{$\begin{array}{c}\text { Incidence } \\
(\%)\end{array}$} & \multicolumn{2}{|c|}{$\begin{array}{c}\text { Severity } \\
(\%)\end{array}$} & \multirow{2}{*}{$\begin{array}{c}\text { Incidence } \\
(\%)\end{array}$} & \multicolumn{2}{|c|}{$\begin{array}{c}\text { Severity } \\
(\%)\end{array}$} & \multirow{2}{*}{$\begin{array}{c}\text { Incidence } \\
(\%)\end{array}$} & \\
\hline & & $\overline{\bar{x}}$ & & & $\overline{\bar{x}}$ & $S$ & & $\overline{\bar{X}}$ & & & $\overline{\bar{x}}$ & $S$ & & \\
\hline \multicolumn{14}{|l|}{ Diseases } & \\
\hline Early blight & 0.0 & . & & 0.0 & . & & 12.0 & 1.0 & 4.7 & 0.5 & 0.01 & 0.07 & 3.5 & 1 \\
\hline Late blight & 97.0 & 26.5 & 15.3 & 95.0 & 21.7 & 15.6 & 2.0 & 0.1 & 0.5 & 90.5 & 21.1 & 16.1 & 20.5 & \\
\hline Black leg ${ }^{1}$ & 0.0 & . & . & 1.5 & . & 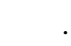 & 1.0 & . & . & 0.0 & . & . & 0.0 & \\
\hline Stem cancker ${ }^{1}$ & 4.0 & . & . & 0.5 & . & . & 0.0 & . & . & 1.0 & . & . & 0.0 & \\
\hline Common rust & 34.0 & 1.2 & 2.4 & 0.0 & 0.0 & 0.0 & 0.0 & 0.0 & . & 49.0 & 6.2 & 8.0 & 1.0 & \\
\hline \multicolumn{14}{|c|}{ Insect damages } & \\
\hline White grub ${ }^{1}$ & 0.0 & . & & 7.0 & . & & 0.0 & & . & 0.0 & . & & 0.0 & \\
\hline Wireworm ${ }^{2}$ & 18.0 & . & . & 0.0 & . & . & 0.0 & . & . & 0.0 & . & . & 0.0 & \\
\hline Andean weevil & 13.0 & 1.0 & 3.3 & 17.0 & 2.5 & 7.3 & 0.0 & . & - & 0.5 & 0.01 & 0.1 & 0.0 & \\
\hline Whitefly ${ }^{3}$ & 0.0 & 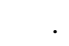 & & 0.0 & 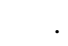 & & 0.0 & . & 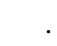 & 0.0 & 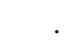 & & 0.0 & \\
\hline Leafminer & 28.0 & 1.8 & 3.5 & 0.5 & 0.1 & 0.7 & 13.0 & 0.3 & 1.0 & 15.0 & 1.2 & 3.0 & 43.0 & \\
\hline Aphids $^{4}$ & 0.0 & 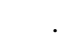 & . & 0.0 & . & . & 0.0 & . & 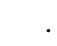 & 17.0 & . & & 0.0 & \\
\hline Flea beetle & 5.0 & 0.4 & 1.9 & 3.5 & 0.2 & 1.3 & 96.0 & 9.2 & 6.1 & 1.5 & 0.1 & 0.6 & 30.0 & \\
\hline Thrips & 87.0 & 13.5 & 13.6 & 22.0 & 1.6 & 3.3 & 0.0 & & & 86.0 & 16.8 & 13.6 & 32.5 & \\
\hline
\end{tabular}

${ }^{1}$ Severity was not estimated because plants were killed by the pest. ${ }^{2}$ Percentage of plants where insects were present, symptoms not registered.

Potato flea beetle and thrips were frequently found during the monitoring. The average incidence of the potato flea beetle was $39.2 \%$ and the severity $5.7 \%$ with the lowest incidence found on INIAP-Fripapa (1.5\%) and the highest on Única (99\%). Average incidence of thrips was $37.9 \%$. We did not find thrips on the plants of INIAP-Yana Shungo and Única, but these were found on $87 \%$ of plants of the variety Dolores.

We found 19 seed-borne pests and three physical and physiological blemishes. Diseases found on the seed tubers were: black leg (Pectobacterium sp.), black scurf (Rhizoctonia solani), fusarium dry rot (Fusarium sp.), silver scurf (Helminthosporium sp.), powdery scab (Spongospora subterranea), and cracking, i.e., term used to describe symptoms induced by $R$. solani (elephant hide), Streptomyces spp. and other cracking like symptoms. Insect damages were caused by the Andean potato weevil (Premnotrypes vorax), potato flea beetle (Epitrix sp.), potato tuber moth complex (Tecia solanivora, Symmetrischema tangolias, or Phthorimaea operculella), white grub (Barotheus spp.), and wireworm (Agriotes spp.). The most prevalent diseases were black scurf and cracking. Average incidence of black scurf was $80.5 \%$ and severity was $3.2 \%$. The lowest incidence of black scurf was in variety INIAP-Yana Shungo (42\%) and the highest was in Única (95.8\%). Cracking was the second most important problem affecting seed quality. Average 
incidence was $18.3 \%$ and average severity was $0.6 \%$. Chaucha Roja was the least affected variety (1.5\% incidence) while
INIAP-Gabriela was the most affected $(37.3 \%)$.

Table 3. Incidence and severity of seed borne diseases, insect pests, and physical and physiological blemishes in six potato varieties in Ecuador (for the number of observations see Materials and Methods).

\begin{tabular}{|c|c|c|c|c|c|c|c|c|c|c|c|c|c|}
\hline & \multicolumn{3}{|c|}{ Dolores } & \multicolumn{3}{|c|}{ Chaucha Roja } & \multicolumn{3}{|c|}{ INIAP-Yana Shungo } & \multicolumn{3}{|c|}{ INIAP-Fripapa } & \multirow{3}{*}{$\begin{array}{c}\text { INIAP-G } \\
\begin{array}{c}\text { Incidence } \\
(\%)\end{array} \\
\bar{X}\end{array}$} \\
\hline & \multirow{2}{*}{$\begin{array}{c}\text { Incidence } \\
(\%)\end{array}$} & \multicolumn{2}{|c|}{$\begin{array}{c}\text { Severity } \\
(\%)\end{array}$} & \multirow{2}{*}{$\begin{array}{c}\begin{array}{c}\text { Incidence } \\
(\%)\end{array} \\
\bar{X}\end{array}$} & \multicolumn{2}{|c|}{$\begin{array}{c}\text { Severity } \\
(\%)\end{array}$} & \multirow{2}{*}{$\begin{array}{c}\begin{array}{c}\text { Incidence } \\
(\%)\end{array} \\
\bar{X} \\
\end{array}$} & \multicolumn{2}{|c|}{$\begin{array}{c}\text { Severity } \\
(\%)\end{array}$} & \multirow{2}{*}{$\begin{array}{c}\begin{array}{c}\text { Incidence } \\
(\%)\end{array} \\
\bar{X}\end{array}$} & \multicolumn{2}{|c|}{$\begin{array}{c}\text { Severity } \\
(\%)\end{array}$} & \\
\hline & & $\overline{\bar{x}}$ & $\overline{\mathbf{S}}$ & & $\overline{\bar{x}}$ & $\overline{\mathbf{S}}$ & & $\overline{\bar{x}}$ & $\overline{\mathbf{S}}$ & & $\overline{\bar{x}}$ & $\overline{\mathbf{S}}$ & \\
\hline \multicolumn{14}{|l|}{ Diseases } \\
\hline Cracking & 14.5 & 0.3 & 1.0 & 1.5 & 0.0 & 0.4 & 8.0 & 0.1 & 0.3 & 33.3 & 1.1 & 3.6 & 37.3 \\
\hline Fusarium dry rot & 3.0 & 0.5 & 5.7 & 35.8 & 3.0 & 7.3 & 3.0 & 0.2 & 1.4 & 6.8 & 0.3 & 1.8 & 0.3 \\
\hline Silver scurf & 0.0 & 0.0 & . & 0.0 & 0.0 & . & 0.0 & 0.0 & . & 4.8 & 0.3 & 1.6 & 0.0 \\
\hline Black leg & 0.0 & 0.0 & . & 1.0 & 0.8 & 8.0 & 2.0 & 0.5 & 4.1 & 0.0 & 0.0 & . & 0.0 \\
\hline Black scurf & 88.5 & 5.1 & 6.2 & 83.3 & 2.6 & 3.3 & 42.0 & 0.4 & 0.6 & 85.0 & 2.4 & 6.8 & 88.3 \\
\hline Powdery scab & 0.0 & 0.0 & . & 0.0 & 0.0 & . & 0.0 & 0.0 & . & 0.3 & 0.0 & 0.5 & 0.5 \\
\hline \multicolumn{14}{|l|}{ Virus } \\
\hline APLV & 0.0 & . & . & 0.0 & . & . & 19.5 & . & . & 0.0 & . & . & 9.0 \\
\hline APMoV & 0.0 & . & . & 0.0 & . & . & 0.0 & . & . & 0.0 & . & . & 6.0 \\
\hline PLRV & 0.0 & . & . & 0.0 & . & . & 2.4 & . & . & 1.0 & . & . & 1.0 \\
\hline PVA & 0.0 & . & . & 0.0 & . & . & 0.0 & . & . & 0.0 & . & . & 5.0 \\
\hline PVS & 100.0 & . & . & 18.0 & . & . & 85.4 & . & . & 0.0 & . & . & 4.0 \\
\hline PVX & 88.0 & . & . & 100.0 & . & . & 0.0 & . & . & 2.0 & . & . & 30.0 \\
\hline PVY & 2.0 & . & . & 0.0 & . & . & 2.4 & . & . & 2.0 & . & . & 9.0 \\
\hline PYVV & 0.0 & . & . & 0.0 & . & . & 2.4 & . & . & 2.0 & . & . & 11.0 \\
\hline \multicolumn{14}{|l|}{ Insects damages } \\
\hline White grub & 10.5 & 0.4 & 1.8 & 5.0 & 0.2 & 1.7 & 16.5 & 1.8 & 7.4 & 1.0 & 0.0 & 0.6 & 6.8 \\
\hline Wireworm & 11.5 & 0.2 & 0.7 & 1.3 & 0.0 & 0.3 & 0.0 & 0.0 & . & 8.5 & 0.1 & 0.7 & 15.8 \\
\hline Andean weevil & 82.5 & 14.4 & 18.8 & 61.8 & 4.2 & 9.1 & 33.5 & 1.7 & 4.5 & 45.3 & 3.4 & 7.8 & 53.8 \\
\hline Tuber moth complex & 0.0 & 0.0 & . & 2.8 & 0.1 & 0.5 & 0.0 & 0.0 & . & 0.0 & 0.0 & 0.0 & 0.0 \\
\hline Flea beetle & 0.0 & 0.0 & . & 0.0 & 0.0 & . & 0.0 & 0.0 & . & 0.0 & 0.0 & . & 1.0 \\
\hline \multicolumn{14}{|c|}{$\begin{array}{l}\text { Physical and physiological } \\
\text { issues }\end{array}$} \\
\hline Mechanical damage & 2.5 & . & . & 10.0 & . & . & 10.5 & . & . & 14.5 & . & . & 13.5 \\
\hline Misshappen tubers & 0.5 & . & . & 1.5 & . & . & 12.5 & . & . & 2.3 & . & . & 0.0 \\
\hline Inmature tubers & 35.0 & . & . & 51.5 & . & - & 99.5 & & . & 0.8 & . & . & 63.0 \\
\hline
\end{tabular}

Andean weevil and white grub. Average incidence of the damage of Andean weevil was $46.4 \%$ with a severity of $4.7 \%$. The least affected variety was Única (1.5\% incidence) and the most affected was Dolores (82.5\%). Damage caused by white grubs was found in $8.3 \%$ of tubers with a severity of $0.6 \%$. The least affected variety was INIAP-Fripapa (1\% of incidence) and the most affected variety was INIAP-Yana Shungo (16.5\%). Tubers with symptoms of tuber blight ( $P$. infestans) were not found in this study.
Virus diagnosis revealed that $38.0 \%$ of the tubers sampled were clean, $45.1 \%$ were infected with one virus, $16.3 \%$ were infected with two, and $0.01 \%$ were infected with three. Infections with more than three viruses were not found on the sample. PVS had the highest incidence (46.2\%) followed by PVX (43.8\%). PVS was not found on INIAP-Fripapa, but in all the tubers of Dolores. Similarly, PVX was not present on INIAP-Yana Shungo, but it was found in all the tubers of Chaucha Roja. Incidences of PVA and APMoV were low $(0.8$ and $1 \%$, 
respectively and only found in the variety INIAP-Gabriela in 5\% and 6\% of the tubers, respectively. PVX and PVS were present simultaneously in $11 \%$ of the tubers. Other simultaneous viral infections were low (incidence $<2 \%$ ), these were: APLV+PLRV $=0.7 \%$, APLV+PVS $=1.7 \%, \quad$ APLV $+\mathrm{PVX}=1 \%$, APLV+PVY $=0.4 \%$, $\mathrm{APMoV}+\mathrm{PVA}=0.8 \%$, $\mathrm{APMoV}+\mathrm{PVS}=0.2 \%$, $\mathrm{APMoV}+\mathrm{PVX}=0.1 \%$, APMoV+PYVV=0.1\%, $\mathrm{PLRV}+\mathrm{PVX}=0.8 \%, \quad \mathrm{PVA}+\mathrm{PVX}=0.2 \%$, $\mathrm{PVS}+\mathrm{PVY}=0.4 \%, \quad \mathrm{PVS}+\mathrm{PYVV}=0.5 \%$, $\mathrm{PVX}+\mathrm{PVY}=0.4 \%, \quad \mathrm{PVX}+\mathrm{PYVV}=0.5$, $\mathrm{PYV}+\mathrm{PYVV}=0.2 \%$, $\mathrm{PVX}+\mathrm{PVY}+\mathrm{PVS}=0.001 \%$, $\mathrm{PVX}+\mathrm{PVS}+\mathrm{PYVV}<0.001 \%$, $\mathrm{PVX}+\mathrm{PVS}+\mathrm{APLV}<0.001 \%$,

\section{Seed-borne pest and pathogen diversity}

Pest and pathogen diversity on the seed tubers was assessed using the Shannon diversity index where a larger index indicates a larger diversity. Taking into account all pests and diseases, the Shannon diversity indexes were the following: Dolores: 1.12 ( $n=103$ tubers); INIAP-Fripapa: $1.62(n=240)$; Chaucha Roja: 1.94 ( $n=404)$; INIAP-Yana Shungo: $2.18(n=90)$; Única: $2.39(n=$ 286); and INIAP-Gabriela: $2.71(n=$ 237). The Shannon diversity index for all the pests did not show any relationship with the altitude. However, we found a negative correlation with altitude when the Shannon diversity index was calculated for viruses only (A). The
PVX+PLRV+APLV $<0.001 \%$, $\mathrm{PVX}+\mathrm{APMoV}+\mathrm{PVA}<0.001 \%$, $\mathrm{PVY}+\mathrm{PVS}+\mathrm{APLV}=0.001 \%$.

Three physical and physiological blemishes were found during this monitoring: mechanical damages, misshapen tubers, and inmature tubers. Interestingly, almost half of the tubers sampled were found to be inmature $(47.2 \%)$. The lowest incidence of inmature tubers was found on the variety INIAP-Fripapa $(0.8 \%)$, while the highest was found on the variety INIAP-Yana Shungo (99.5\%). A small portion of misshapen tubers were found during this sampling (3\%). All the tubers of the variety INIAP-Gabriela had the variety's tuber shape at harvest, while $12.5 \%$ of the tubers of the variety INIAP-Yana Shungo were misshapen.

coefficient of determination $\left(\mathrm{R}^{2}\right)$ indicated that the altitude explained $6 \%$ of the variability of the Shannon diversity index when including all varieties (A, dashed line), and $22 \%$ when excluding INIAP-Gabriela (A, full line). Considering all pests and pathogens, we found no differences in the Shannon diversity index among tubers harvested from different seed sources $(p>0.05)$ (B): tubers produced with seed from the formal system had a Shannon diversity index of 1.7 ( $\mathrm{sd}=0.5 ; n=330$ tubers); tubers coming from seed from the market: 1.67 ( $\mathrm{sd}=0.6 ; n=360)$; and tubers coming from seed which was selfprovided by the farmer: $1.82(\mathrm{sd}=0.6 ; n$ $=670$ ). 
A

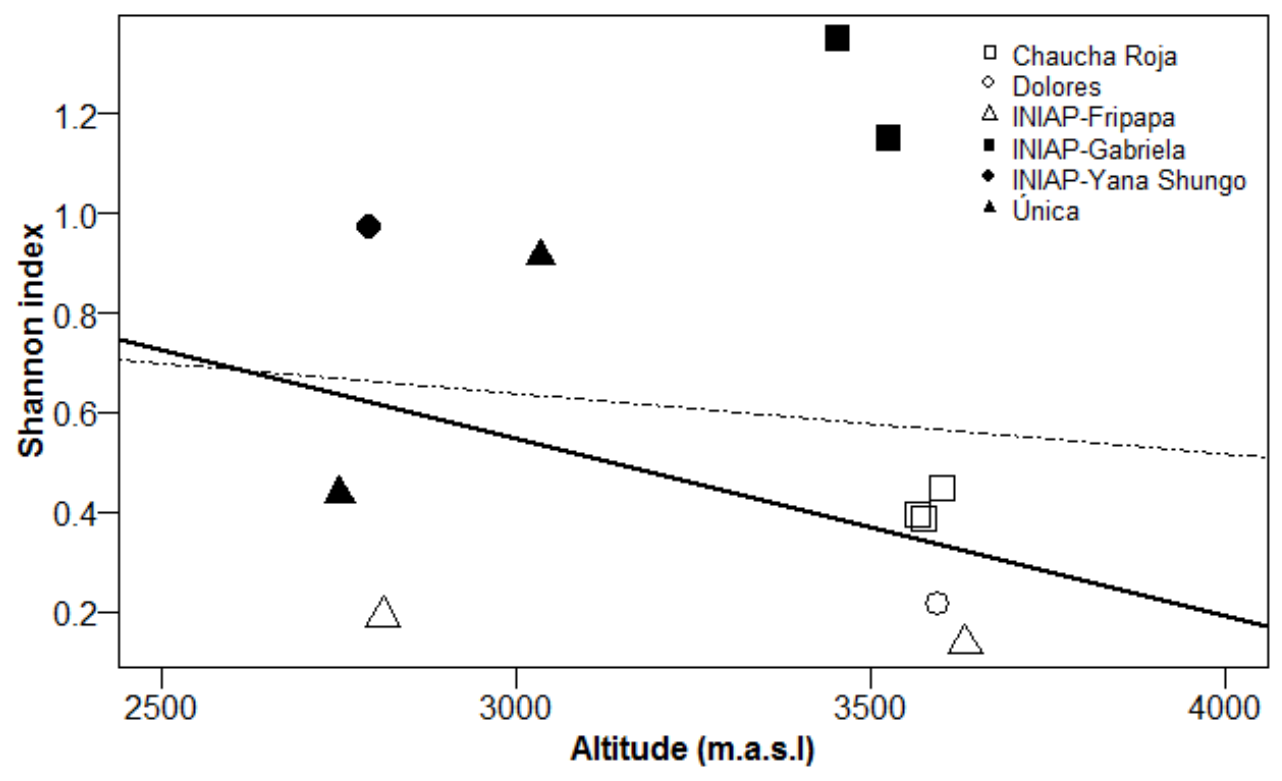

B

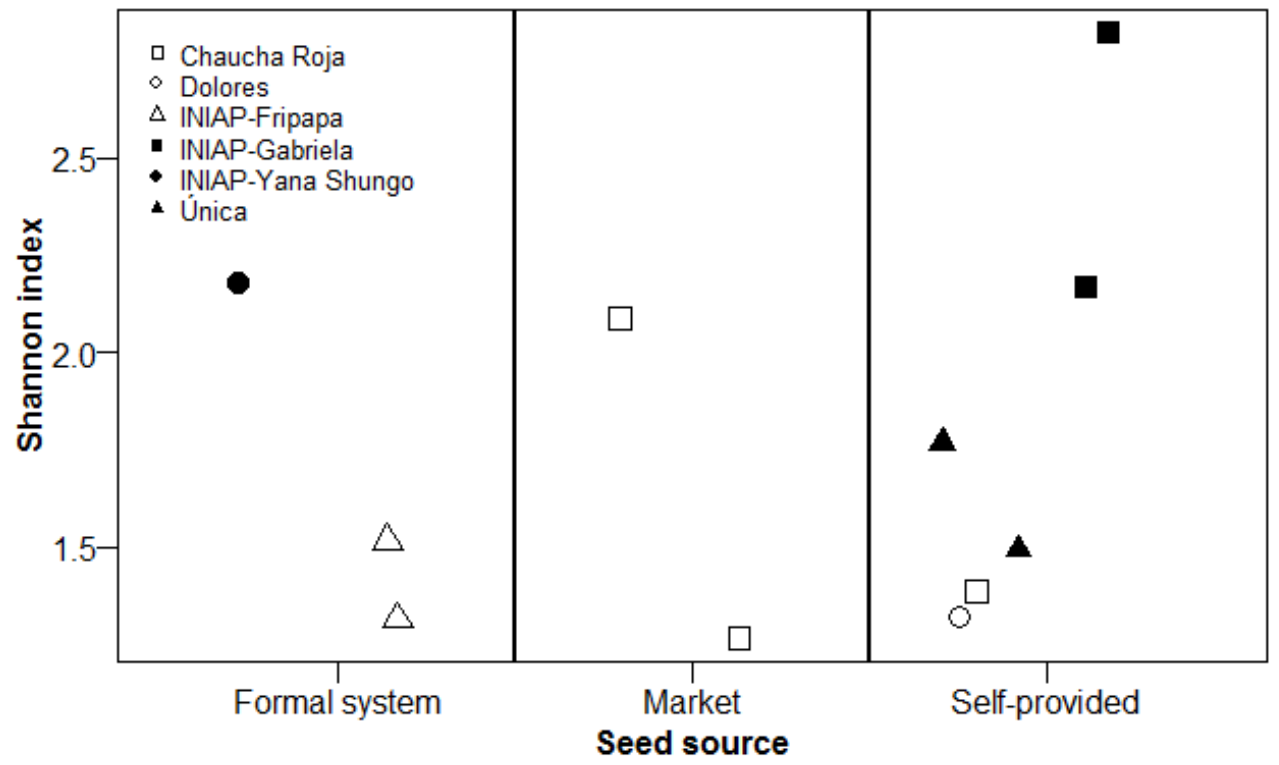

Figure 1. Seed borne pest diversity on seed tubers monitored in three provinces in Ecuador. A. Effect of the altitude on virus diversity: dashed line represents a model including all varieties $\left(\mathrm{R}^{2}=6 \%\right)$, and full line a model excluding INIAPGabriela $\left(\mathrm{R}^{2}=22 \%\right)$. B. Pest diversity on tubers according to the three seed sources. 


\section{Yield losses caused by seed-borne pests}

Average yield during the field experiment was $1010.5 \mathrm{~g} \mathrm{plant}^{-1}(\mathrm{sd}=785.8)$ and, as expected, there were large differences among varieties: Chaucha Roja: $437.1 \mathrm{~g}$ plant $^{-1}(\mathrm{sd}=298.4)$; Dolores: $595.8 \mathrm{~g}$ plant $^{-1}(\mathrm{sd}=252.7) ;$ INIAP-Fripapa $1150.1 \mathrm{~g} \mathrm{plant}^{-1}(\mathrm{sd}=417.9)$; INIAPGabriela: $2262.8 \mathrm{~g} \mathrm{plant}^{-1}(\mathrm{sd}=717.1)$; INIAP-Yana Shungo: $883.8 \mathrm{~g} \mathrm{plant}^{-1}$ (sd = 515.8); and Única: $734.9 \mathrm{~g} \mathrm{plant}^{-1}(\mathrm{sd}=$ 454.7).

Before describing the models obtained in this section, it is worth to note that the factor of varieties was an important driver for yield variation. It was able to explain $65 \%$ of the variability in yield, but it was excluded from the analysis due to problems of multicollinearity.

The multiple linear regression identified ( $n=1103$ observations) four significant parameters interacting with the varieties studied: presence or absence of PVS, PYVV and mechanical damage, and severity $(\%)$ of black scurf on the seed tuber (Table 4). Multiple regressions grouped by seed source were different. The multiple linear regression for tubers produced with farmers' self-provided seed had an $\mathrm{R}^{2}$ (coefficient of determination) of $40 \%$, and predicted and average yield of $1739.2 \mathrm{~g} \mathrm{plant}^{-1}$. It detected the presence and absence of PVS and PYVV as important factors explaining yield variability. PVS had a negative influence over the yield explaining $38 \%$ of the variability while the presence or absence of PYVV has a positive influence on yield explaining $2 \%$ of the variability (Table 4). The model estimated for the tubers produced with seed tubers acquired in the market showed a lower $\mathrm{R}^{2}$ of $7 \%$ with an average yield of $375.3 \mathrm{~g} \mathrm{plant}^{-1}$. It identified the severity of black scurf as the only important factor affecting positively yield (Table 4). The regression for the tubers produced with seed tubers acquired from the formal system had an $\mathrm{R}^{2}$ of $7 \%$ and estimated an average yield of $1181.6 \mathrm{~g}$ plant $^{-1}$. The model identified two significant parameters that had a negative influence on yield, presence and absence of PVS and mechanical damage (Table 4).

Regressions were different among varieties which $\mathrm{R}^{2}$ ranged from 8 to $11 \%$. For Chaucha Roja, the model $\left(\mathrm{R}^{2}=8 \%\right)$ found the presence and absence of PVS and severity of black scurf as significant predictors affecting yield. PVS had a negative influence on yield while severity of black scurf had a positive influence on yield. For INIAP-Fripapa $\left(\mathrm{R}^{2}=9 \%\right)$, the regression identified only the presence or absence of mechanical damage as significant parameter for yield variation. For INIAP-Gabriela $\left(\mathrm{R}^{2}=9 \%\right)$, three predictors were detected: presence or absence of PVS, presence or absence of PYVV, and severity of black scurf. PVS had a negative effect on yield variation while black scurf and PYVV had a positive effect on yield variation. For variety INIAP-Yana Shungo $\left(\mathrm{R}^{2}=11 \%\right)$, the model identified the presence or absence of mechanical damage as the only predictor of yield variability. For Unica $\left(\mathrm{R}^{2}=11 \%\right)$, the regression detected two predictors: presence or absence of PVS and severity (\%) of black scurf. PVS had a negative effect on yield variation while black scurf had a positive effect on yield variation. The model for variety Dolores was not estimated since the contribution of the parameters to the variation in yield was not significant. 


\section{Discussion}

Main findings of this study were the following: (1) in the foliage, the most important pests were late blight and potato flea beetle, while in the tubers the most important were black scurf and Andean potato weevil; viruses with the highest incidences were PVS and PVX; (2) altitude had a negative effect on virus diversity and explained between 6 and $22 \%$ of its variability; pest diversity was similar in tubers harvested from different seed sources; (3) models estimating yield responses were different when grouped by seed source or varieties. Due to the fact that the monitoring and the field experiment were performed in a single year (2010-2011) omitting replicates, conclusions from this study have to be taken cautiously.

\section{Incidence and severity of seed-borne pests}

The most important foliage disease found was late blight. This disease was present in $65.9 \%$ of the plants assessed, indicating that it is still one of the main biotic factors limiting the productivity in the country as suggested by Hijmans et al. (2000) and Oyarzún et al. (2001). Damages of potato flea beetle follow late blight in importance with an incidence $39.2 \%$. Although, we were aware about the importance about this pest, it is the first time that data about damage of potato flea beetle is reported in Ecuador.

Black scurf and Andean potato weevil where the pests that showed the highest incidences on tubers. Black scurf was present in the $80.5 \%$ of the tubers sampled, however, low severities were detected (mean $=3.2 \%, \quad \mathrm{sd}=1.7$, Fankhauser (2000) reported similar results about incidence of black scurf when sampling tubers of the varieties
INIAP-Gabriela and INIAP-Esperanza in the province Chimborazo $(78 \%$ incidence). Incidence of the Andean potato weevil was also high $(46.4 \%)$ but approximately $50 \%$ less than previously reported by Fankhauser (2000) (88\% incidence). These results may indicate that management strategies to control $R$. solani proposed by local organizations are not working, or are not being adopted by farmers since the incidence of black scurf remain stable from 1998 to 2010, when Fankhauser (2000) and our group did the monitoring. Our experience suggest a poor adoption of the management strategies by farmers, and points out the need of strengthening local extension services (Parsa et al. 2012). In contrast, incidence of Andean potato weevil has dropped nearly $50 \%$, from $88 \%$ in 1998 to $43.9 \%$ in 2010 , suggesting better adoption of integrated management practices, more efficient insecticides, or other causes (e.g., an unforeseen effect of climate change on the population of Premnotrypes vorax). Despite this incidence reduction, Andean weevil is one of the main concerns for seed potato farmers in Ecuador (Buddenhagen et al. 2017).

Cracking symptoms were found on the $18.3 \%$ of the tubers sampled. This high incidence reported might be the result of the use of "cracking" as a generic term to refer to symptoms that could be produced either by R. solani, Streptomyces spp., or other causes, and suggest the need for a specific study to define the etiology of cracking.

Our results confirm that the presence of tuber blight in the country is limited. A previous research found similar incidences of tuber blight on farmer fields 
in the provinces of Bolivar, Cañar, Carchi, Chimborazo, Pichincha and Tungurahua (Oyarzún et al. 2005). Probably, the low incidence of tuber blight found is associated with the soil microbiological and physical-chemical characteristics affecting the development of the disease (Garzón and Forbes 1999, Villamarin et al. 2011). In spite of it, special attention should be given to tuber blight since there is evidence of preemergence infection caused by $P$. infestans in Ecuador (Kromann et al. 2008).

Viruses have been considered the main factors to reduce seed quality. In our study, we showed that PVS and PVX were the most prevalent viral problems, found in $46.2 \%$ and $43.8 \%$ of the tubers sampled, respectively. Surveys performed findings of Sanchez de Luque et al. (1991) and Fankhauser (2000) where they report higher incidences of PVX, PVS, PVY, PLRV and PYVV at lower altitudes than at higher altitudes. Our results supports the beneficial effects of the traditional on-farm practice of using seed tubers produced at high altitudes as an strategy to improve seed quality (Thiele 1999). However, specific experiments should be considered to confirm these findings, and determine the effect of the seed tubers produced at higher altitudes when planted at lower altitudes on the productivity and seed quality.

Our findings show that, at the time the monitoring was done, the quality of the tubers produced with seed coming from different sources was similar (B). A similar previous observation was done by Bertschinger et al. (1990). It is expected that seed quality, in Ecuador, improves in the next years due to a large governmental investment on seed tuber replacement with certified seed. However, as previously mentioned, our results point in Peru during 1985-1987 and in Ecuador in 1998 also found that both of these viruses were predominant in farmers' fields (Bertschinger et al. 1990, Fankhauser 2000). On the contrary, recent research points out to a high incidence of PVY in the varieties INIAP-Fripapa and Superchola (Gomez et al. 2015), but such contrast might be influenced by the seed source. This variation in results stresses out the importance of monitoring diseases and pests to understand how ecological conditions, on-farm management practices, seed sources and planted variety determine viral incidence.

\section{Seed-borne pest and pathogen diversity}

We found that altitude has a negative effect on virus diversity. Our results support the out to the weaknesses in the formal seed production system that does not allow farmers to perceive the advantage of using high quality seed tuber. Additionally, these results highlight the importance to fine-tune on-farm seed management practices that promote the increase of seed quality, and to acquire a better understanding of the seed system and seed sources in Ecuador to support the dissemination of high quality seed to farmers.

\section{Yield losses caused by seed-borne pests}

Models estimating yield responses were different between seed sources. PVS and PYVV explained yield variation when seed was self-provided by farmers, black scurf when seed was acquired from the market, and PVS and mechanical damage when seed was obtained from the formal system. Additionally, the effect of seed quality per variety over yield responses was different (Table 4). For instance, the regression model for Chaucha Roja $\left(\mathrm{R}^{2}=\right.$ $8 \%$ ) identified that the presence of PVS 
and severity of black scurf in the seed tuber explained yield variation, while for INIAP-Fripapa, only the presence of mechanical damage had an influence (Table 4).

Several studies have shown an increase on yield up to $50 \%$ when using seed tuber in optimal physiological and quality conditions in comparison with farmer seed tubers (Alvarez 1988, Bertschinger et al. 1995, Wissar 1995, Andrade et al. 2008, Gildemacher et al. 2011, Garzón 2014). However, these studies have ignored the complexity of interactions (synergy and antagonism) between seedborne pests and pathogens in multiple contexts (e.g. different soils, environments, and host-pest-pathogen interactions). Inconsistencies of our models (Table 4) suggest that current methodological approaches to understand how seed quality correlates with yield variation in multiple contexts need still to be further improved, and highlight the relevance of understanding interactions between the different varieties and the seed-borne pest/pathogens to establish indicators that define seed quality. Similar considerations were mentioned by Thomas-Sharma et al. (2016).

PVS was consistently identified in our models (Table 4) as one the main drivers for yield decline during the period 20102011. Additionally, our models per seed source estimate that losses caused by this virus could reach up to $38 \%$. Losses in yield caused by this virus alone are variable but reports mention that it is able to reduce up to $20 \%$ of yield (Manzer et al. 1978, Hooker 1981). Special attention need to be given to this virus since the results of our monitoring revealed a high level of incidence. 
Tabla 4. Main seed borne pest affecting yield variation, Quito, Pichincha. 2012

\begin{tabular}{|c|c|c|c|}
\hline Parameter $^{1,2}$ & Observations & $\begin{array}{c}\text { Coefficient } \\
\left(\text { g plant }^{-1}\right)\end{array}$ & $\begin{array}{c}\text { Partial R-squared } \\
(\%)\end{array}$ \\
\hline \multicolumn{4}{|l|}{ Models per seed source } \\
\hline $\begin{array}{l}\text { Self-provided } \\
\text { Intercept } \\
\text { PVS } \\
\text { PYVV } \\
\text { Total R-squared } \\
\end{array}$ & 539 & $\begin{array}{c}1739.2 \\
-1180.0 \\
815.2\end{array}$ & $\begin{array}{r}38 \\
2 \\
40 \\
\end{array}$ \\
\hline $\begin{array}{l}\text { Market } \\
\text { Intercept } \\
\text { Black scurf } \\
\text { Total R-squared } \\
\end{array}$ & 267 & $\begin{array}{r}375.3 \\
24.0\end{array}$ & $\begin{array}{l}7 \\
7 \\
\end{array}$ \\
\hline $\begin{array}{l}\text { Formal system } \\
\text { Intercept } \\
\text { PVS } \\
\text { Mechanical damage } \\
\text { Total R-squared } \\
\end{array}$ & 297 & $\begin{array}{l}1181.6 \\
-280.7 \\
-184.4\end{array}$ & $\begin{array}{l}5 \\
2 \\
7\end{array}$ \\
\hline \multicolumn{4}{|l|}{ Models per variety } \\
\hline $\begin{array}{l}\text { Chaucha Roja } \\
\text { Intercept } \\
\text { PVS } \\
\text { Black scurf } \\
\text { Total R-squared } \\
\end{array}$ & 292 & $\begin{array}{r}388.6 \\
-111.5 \\
23.8\end{array}$ & $\begin{array}{l}1 \\
7 \\
8\end{array}$ \\
\hline $\begin{array}{l}\text { INIAP-Fripapa } \\
\text { Intercept } \\
\text { Mechanical damage } \\
\text { Total R-squared } \\
\end{array}$ & 221 & $\begin{array}{r}1220.6 \\
-299.6\end{array}$ & $\begin{array}{l}9 \\
9 \\
\end{array}$ \\
\hline $\begin{array}{l}\text { INIAP-Gabriela } \\
\text { Intercept } \\
\text { PVS } \\
\text { Black scurf } \\
\text { PYVV } \\
\text { Total R-squared } \\
\end{array}$ & 197 & $\begin{array}{r}2178.9 \\
-944.1 \\
18.8 \\
526.1\end{array}$ & $\begin{array}{l}3 \\
2 \\
4 \\
9 \\
\end{array}$ \\
\hline $\begin{array}{l}\text { INIAP- Yana Shungo } \\
\text { Intercept } \\
\text { Mechanical damage } \\
\text { Total R-squared } \\
\end{array}$ & 76 & $\begin{array}{l}835.8 \\
730.0\end{array}$ & $\begin{array}{l}11 \\
11 \\
\end{array}$ \\
\hline $\begin{array}{l}\text { Única } \\
\text { Intercept } \\
\text { PVS } \\
\text { Black scurf } \\
\text { Total R-squared }\end{array}$ & 223 & $\begin{array}{r}925.8 \\
-251.4 \\
7.2\end{array}$ & $\begin{array}{r}8 \\
3 \\
11 \\
\end{array}$ \\
\hline
\end{tabular}

PYVV was identified as one of the factors explaining a positive effect on yield variation (partial $R^{2}$ of the model for seed self-provided $=2 \%$; and partial $\mathrm{R}^{2}$ for the model of INIAP-Gabriela $=4 \%$ ). In our case, this effect was driven by a single variety, INIAP-Gabriela, in which infected plants (see Incidence of PYVV 
on Table 3) showed a higher yield (2689.2 g plant $^{-1} ; \mathrm{sd}=811.5$ ) than healthy plants $\left(2222.5 \mathrm{~g} \mathrm{plant}^{-1}\right.$; sd $\left.=696.6\right)(\mathrm{t}-$ test: $p<0.01$. Salazar (2006) and Guzmán-Barney et al. (2012), on the contrary, indicated that yield is highly reduced in the presence of PYVV and is an emerging disease in Andes. The unusual response of INIAP-Gabriela to PYVV proposes a promising case of investigation to understand this interaction, but also other interactions due to the fact that this variety registered the highest seed-borne pest and pathogen diversity (Figure 1 and Table 3) and the highest yield (Table 4).

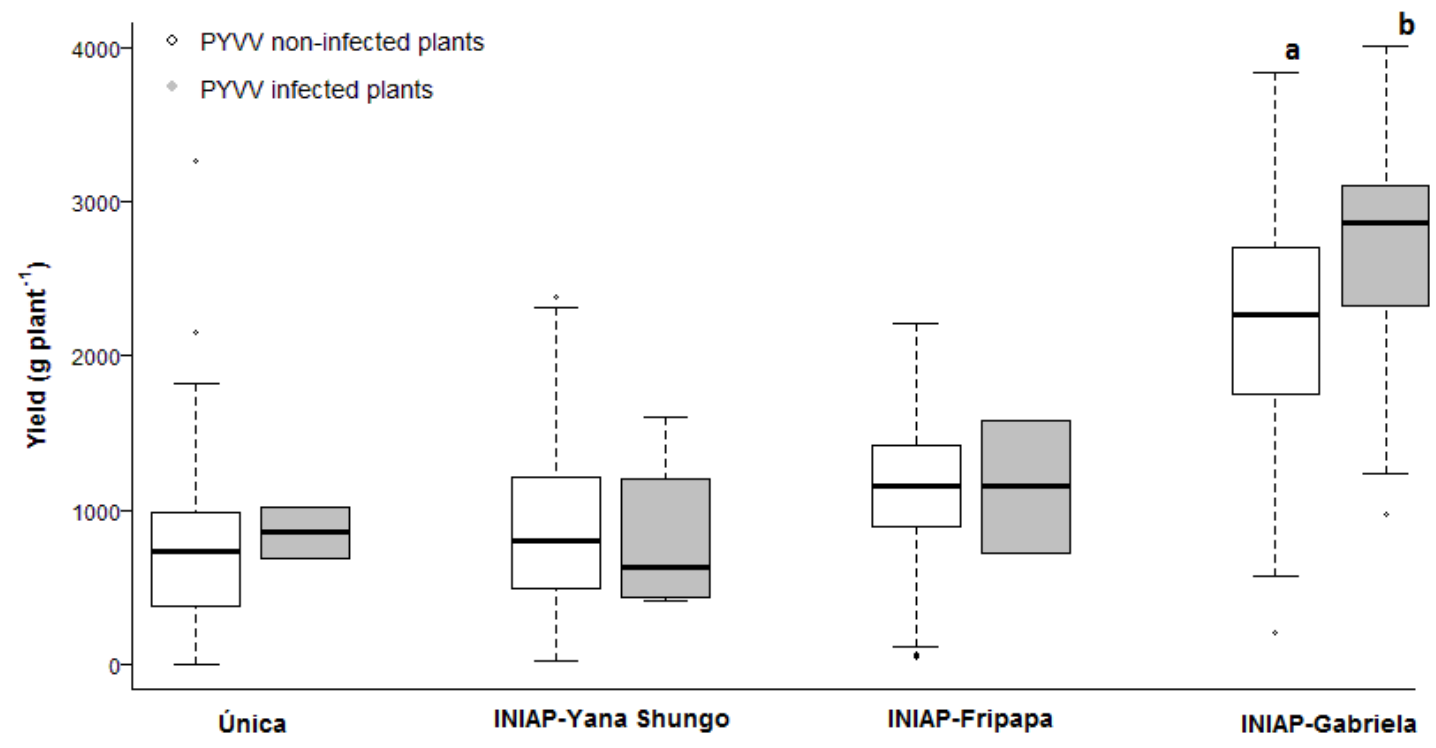

Figure 2. Effect of the presence of PYVV on yield in 4 potato varieties. Yield difference in the variety INIAPGabriela was analysed by a t-test. Different letters indicate significant differences according to the t-test $(\mathrm{p}<$ 0.01). The incidence of PYVV in each variety is in Table 3.

$R$. solani is able to induce yield losses up to $30 \%$ on farmer fields (Banville 1989). However, the influence of this pathogen is remarkably affected by the weather and the on-farm management practices (James and McKenzie 1972, Gudmestad et al. 1979, Hill and Anderson 1989, Atkinson et al. 2010). During our experiment, losses in yield caused by $R$. solani were not detected, although, the model detected this pathogen as an important factor driving increase on yield. It is likely that the lack of enough inoculum density induced an increase on yield since the average severity of black scurf on the seed tuber was $3.23 \%$ of black scurf. Further research would be needed to understand this hypothesis.

The presence of mechanical damage was relevant in our study (partial $\mathrm{R}^{2}$ of the model for seed obtained from the formal seed system $=2 \%$; and partial $\mathrm{R}^{2}$ for the model of INIAP-Fripapa and INIAPYana Shungo $=9 \%$ and $11 \%$ ). The presence of mechanical damage had a negative influence on the yield for the models of the seed obtained from the formal system and INIAP-Fripapa; while it had a positive influence on the yield for the model of INIAP-Yana Shungo. These 
contradicting results might be due to the fact that mechanical damages were registered as either presence or absence. The development of indicators to quantitatively describe mechanical damages could have helped to better estimate losses in yield caused by mechanical damages present on seed tubers.

Despite the fact that our experiment was performed only once without no replicates, our models show that there are several factors affecting yield. We should be cautious at the moment of using this information. Further research is necessary to understand how the seed quality affects yield taking into account genotype characteristics and different complex conditions (implementing different replicates of the experiment). We believe that resistance to seed-borne pathogens should be explore among Ecuadorian varieties to contribute to the improvement of seed quality in the hands of smallholder farmers.

\section{Conflicts of interest}

The authors declare no conflict of interest.

\section{Acknowledgements}

This research was carried out by the project "Strengthening systems for native seed potato in Bolivia, Ecuador and Perú" supported by the McKnight Foundation. We want to acknowledge the support of Fausto Yumisaca, Edwin Pallo, and Fabián Montesdeoca for assistance in the field experiments and fruitful comments; Carlos Barahona and Arturo Taipe for statistical support; and Marcelo Vinueza for technical assistance in the laboratory and glasshouse.

\section{References}

Almekinders, C. J. M.; \& Louwaars, N. P. (2002). The importance of the farmers' seed systems in a functional national seed sector. Journal of New Seeds, 4(1-2), 1533. https://doi.org/10.1300/J153v04n01_02

Alvarez, E. V. (1988). Método simple de selección para la producción de semilla de papa. Revista Latinoamericana de La Papa, $1,18-24$.

Andrade, N.; Contreras, A.; Castro, I. (2008). Evaluación comparativa del efecto en el rendimiento y sanidad en el cultivo de la papa al utilizar semilla certificada y sin certificar. Agro Sur, 36(2), 111-114.

Atkinson, D.; Thornton, M. K.; Miller, J. S. (2010). Development of Rhizoctonia solani on stems, stolons and tubers of potatoes I. Effect of inoculum source. American Journal of Potato Research, 87(4), 374-381. https://doi.org/10.1007/s12230-010-9143-6

Banville, G. J. (1989). Yield losses and damage to potato plants caused by Rhizoctonia solani Kuhn. American Potato Journal, 66(12), 821-834. https://doi.org/10.1007/BF02853963

Bertschinger, L. (1992). Modelling of potato virus pathosystems by means of quantitative epidemiology: An exemplary case based on virus degeneration studies in Peru (PhD). Swiss Federal Institute of Technology, Zurich, Switzerland.

Bertschinger, L.; Scheidegger, U. C.; Muñoz, J.; Hidalgo, A. (1995). Efecto de diferentes virus sobre el rendimiento potencial de la papa y su interacción con el estado de brotamiento de tubérculos-semilla en la costa del Perú. Rev. Latinoam. Papa, 7(8), 36-54.

Bertschinger, L.; Scheidegger, U.; Luther, K.; Pinillos, O.; Hidalgo, A. (1990). La incidencia de virus de papa en cultivares nativos y mejorados en La Sierra Peruana. Rev. Latinoam. Papa, 3(1), 62-79. 
Bourke, A. (1993). "The Visitation of God"? The Potato and the Great Irish Famine. Dublin: Lilliput Press Ltd.

Buddenhagen, C. E.; Hernandez Nopsa, J.F.; Kelsey, A.; Andrade-Piedra, J.; Forbes, G.A.; Kromann, P.; ThomasSharma, S.; Useche, P.; Garrett, G.A.; 2017. Epidemic network analysis for mitigation of invasive pathogens in seed systems: Potato in Ecuador. bioRxiv: 107367. doi:10.1101/107367.

CIP. (1993a). Preparation of 32P-Labeled probes by RNA transcription. In Techniques in plant virology. CIP Training Manual (Jayasinghe, U.; Salazar, L. F). Lima, Peru: International Potato Center (CIP). Retrieved from http://cipotato.org/library/pdfdocs/44035.pd f

CIP. (1993b). Sample preparation for PSTVD detection by nucleic acid hybridization. In Techniques in plant virology. CIP Training Manual (Jayasinghe, U.; Salazar, L. F). Lima, Peru: International Potato Center (CIP). Retrieved from http://cipotato.org/library/pdfdocs/44035.pd $\mathrm{f}$

CIP. (2007). DAS-ELISA kit for potato virus detection (International Potato Center). Lima, Peru.

Cruickshank, G.; Stewart, H. E.; \& Wastie, R. L. (1982). An illustrated assessment key for foliage blight of potatoes. Potato Research, 25(2), 213-214. https://doi.org/10.1007/BF02359807

Dangles, O.; Mesías, V.; Crespo-Perez, V.; Silvain, J.-F. (2009). Crop damage increases with pest species diversity: evidence from potato tuber moths in the tropical Andes. Journal of Applied Ecology, 46(5), 1115-1121. https://doi.org/10.1111/j.1365-

2664.2009.01703.x

Fankhauser, C. (2000). Seed-transmitted diseases as constraints for potato production in the tropical highlands of
Ecuador. Diss., Eidgenössische Technische Hochschule ETH Zürich, Nr. 13770, 2000. Retrieved from http://ecollection.library.ethz.ch/view/eth:3119

FAO. (2016). FAOSTAT. Retrieved November 18, 2016, from http://faostat3.fao.org/browse/Q/QC/E

Faraway, J. J. (2016). Introduction. In Extending the Linear Model with R: Generalized Linear, Mixed Effects and Nonparametric Regression Models, Second Edition (pp. 1-24). Uk: CRC Press.

Fox, J.; Weisberg, S.; Adler, D.; Bates, D.; Baud-Bovy, G.; Ellison, S., ... R-Core. (2016). Package 'car.' Retrieved August 10, 2016, from https://cran.rproject.org/web/packages/car/car.pdf

Garzón, C. (2014). Efecto de cuatro categorias de semilla en el rendimiento de papa (Solanum tuberosum L.) Variedad Superchola. Escuela Superior Politecnica de Chimborazo, Ecuador. Retrieved from http://dspace.espoch.edu.ec/bitstream/1234 56789/3379/1/13T0790\%20GARZON\%20 LOPEZ\%20cesar\%20al\%C3\%A1n.pdf

Garzón, C.; Forbes, G. (1999). Suppression of $P$. infestans in six ecuadorian soils. In Late Blight: A Threat to Global Food Security (p. 117). Quito, Ecuador. Retrieved from https://research.cip.cgiar.org/confluence/do wnload/attachments/37192036/49abstra.pdf ?version $=1 \&$ modificationDate $=127334149$ 1000

Gildemacher, P. R.; Schulte-Geldermann, E.; Borus, D.; Demo, P.; Kinyae, P.; Mundia, P.; Struik, P. C. (2011). Seed potato quality improvement through positive selection by smallholder farmers in Kenya. Potato Research, 54, 253-266. https://doi.org/10.1007/s11540-011-9190-5

Gómez, J.; Navarrete, I.; Taipe, A.; Andrade-Piedra, J.; Kromann, P. (2015). Cuánto degenera la semilla de papa al reutilizarla en sucesivos ciclos de 
producción? Presented at the VI Congreso Ecuatoriano de la Papa, Ibarra,Ecuador.

Gudmestad, N. C.; Zink, R. T.; Huguelet, J. E. (1979). The effect of harvest date and tuber-borne sclerotia on the severity of Rhizoctonia disease of potato. American Potato Journal, 56(1), 35-41. https://doi.org/10.1007/BF02851121

Guzmán-Barney, M.; Franco-Lara, L.; Rodríguez, D.; Vargas, L.; Fierro, J. E. (2012). Yield losses in Solanum tuberosum Group Phureja Cultivar Criolla Colombia in plants with symptoms of PYVV in field trials. American Journal of Potato Research, 89(6), 438-447. https://doi.org/10.1007/s12230-012-9265-0

Hijmans, R. J.; Forbes, G. A.; Walker, T. S. (2000). Estimating the global severity of potato late blight with GIS-linked disease forecast models. Plant Pathology, 49(6), 697-705. https://doi.org/10.1046/j.13653059.2000.00511.x

Hill, C. B.; Anderson, N. A. (1989). An evaluation of potato disease caused by isolates of Rhizoctonia solani AG-3. American Potato Journal, 66(11), 709-721. https://doi.org/10.1007/BF02896827

Hooker, W. J. (1981). Compendium of Potato Diseases. International Potato Center.

James, W. C. (1971). An illustrated series of assessment keys for plant diseases, their preparation and usage. Canadian Plant Disease Survey, 51(2), 39-65.

James, W. C.; McKenzie, A. R. (1972). The effect of tuber-borne sclerotia of Rhizoctonia solani Kühn on the potato crop. American Potato Journal, 49(8), 296301. https://doi.org/10.1007/BF02861667

Kosman, E. (1996). Difference and diversity of plant pathogen populations: A new approach for measuring. Phytopathology, 86(1152-1155). Retrieved from

http://www.apsnet.org/publications/phytopa
thology/backissues/Documents/1996Article s/Phyto86n11_1152.pdf

Kromann, P.; Miethbauer, T.; Ortiz, O.; Forbes, G. (2014). Review of potato biotic constraints and experiences with integrated pest management interventions. In Integrated Pest Management, Pesticide Problems (David Pimentel, Rajinder Peshin, Vol. 3, pp. 245-268). Springer.

Kromann, P.; Taipe, A.; Andrade-Piedra, J. L.; Munk, L.; Forbes, G. A. (2008). Preemergence infection of potato sprouts by Phytophthora infestans in the highland tropics of Ecuador doi:10.1094/PDIS-92-40569. Plant Disease, 92(4), 569-574.

Manzer, F. E.; Merriam, D. C.; Hepler, P. R. (1978). Effects of potato virus $S$ and two strains of potato virus X on yields of Russet Burbank, Kennebec, and Katahdin cultivars in Maine. American Potato Journal, 55(11), 601-609.

https://doi.org/10.1007/BF02852178

Navarrete, I.; Panchi, N., Kromann, P., Forbes, G., and Andrade-Piedra, J. 2016. Dataset for: Health quality of seed potato and yield losses in Ecuador. International Potato Center Dataverse.

Oyarzún, P.; Chamorro, F.; Córdova, J.; Merino, F.; Valverde, F.; Velásquez, J. (2002b). Manejo agronómico. In El Cultivo de Papa en Ecuador (1st ed., pp. 111-113). Ecuador.

Oyarzún, P.; Gallegos, P.; Asaquibay, C.; Forbes, G.; Ochoa, J.; Paucar, B.; ... Yumisaca, F. (2002a). Manejo integrado de plagas y enfermedades. In El Cultivo de Papa en Ecuador (1st ed., pp. 111-113). Ecuador.

Oyarzún, P. J.; Garzón, C. D.; Leon, D.; Andrade, I.; Forbes, G. A. (2005). Incidence of potato tuber blight in Ecuador. American Journal of Potato Research, 82(2), 117-122. https://doi.org/10.1007/BF02853648 
Oyarzún, P.; Taipe, J.; Forbes, G. A. (2001). Phythophthora infestans su actividad y particularidades en el Ecuador. Perfil de País. In Proceedings of the International Workshop Complementing Resistance to Late Blight (Phytophthera Infestans) in the Andes. (E.N. FernándezNorthcote, pp. 17-27). Cochabamba, Bolivia: International Potato Center.

Palacios, M.; Sotelo, G.; Saenz, E. (1997). La polilla de la papa Tecia solanivora (Povolny). In Primer seminario taller internacional sobre manejo integrado de Tecia Solanivora. Ibarra, Ecuador: INIAP Archivo Historico.

Parsa, S.; Ccanto, R.; Olivera, E.; Scurrah, M.; Alcázar, J.; Rosenheim, J. A. (2012). Explaining andean potato weevils in relation to local and landscape features: A facilitated ecoinformatics approach. PLOS ONE, 7(5), e36533. https://doi.org/10.1371/journal.pone.00365 33

Perez, W. G.; Gamboa, J. S.; Falcon, Y. V.; Coca, M.; Raymundo, R. M.; Nelson, R. J. (2001). genetic structure of peruvian populations of Phytophthora infestans. Phytopathology, 91(10), 956-965.

Salazar, L. (1995). Ecología, epidemiología y control de las enfermedades virales. In Los virus de la papa y su control (pp. 177-212). Lima, Peru: International Potato Center.

Salazar, L. (2006). Emerging and reemerging potato diseases in the Andes. Potato Research, 49(1), 43-47. https://doi.org/10.1007/s11540-006-9005-2

Salazar L. (2003). Potato viruses after the XXth century: effects, dissemination and their control.

Sanchez de Luque, C.; Corzo, P.; Perez, O. (1991). Incidencia de virus en papa y su efecto sobre rendimiento en tres zonas agroecológicas de Colombia. Revista Latinoamericana de la Papa, 4, 36-51.

Scholthof, H. B.; Alvarado, V. Y.; VegaArreguin, J. C.; Ciomperlik, J.; Odokonyero, D.; Brosseau, C.; ... Moffett, P. (2011). Identification of an ARGONAUTE for antiviral RNA silencing in Nicotiana benthamiana. Plant Physiol, 156(3), 1548-55. https://doi.org/10.1104/pp.111.178764

SINAGAP. (2017). Producción. Retrieved from

http://sinagap.agricultura.gob.ec/index.php/ reportes-dinamicos-espac

Struik, P. C.; Wiersema, S. G. (1999). Seed potato technology. Wageningen Academic Pub.

Thiele, G. (1999). Informal potato seed systems in the Andes: Why are they important and what should we do with them? World Development, 27(1), 83-99.

Thomas-Sharma, S.; Abdurahman, A.; Ali, S.; Andrade-Piedra, J. L.; Bao, S.; Charkowski, A. O.; ... Forbes, G. A. (2016). Seed degeneration in potato: the need for an integrated seed health strategy to mitigate the problem in developing countries. Plant Pathology, 65(1), 3-16. https://doi.org/10.1111/ppa.12439

Villamarin, D.; Orquera, G.; Mogroviejo, C.; Garzón, C. D.; Molineros, J.; Forbes, G. A.; ... Benitez, M. (2011). Suppressiveness to Phytophthora infestans infection in potato tubers by Andean soils from three provinces of Ecuador. Phytopatholgy, 101, S183.

Wissar, R. (1995). Producción de tubérculos-semillas de papa con pequeños agricultores de la región de Potosí-Bolivia. Revista Latinoamericana de La Papa 7(8): 1 . 